\title{
Polypores from a Brazilian pine forest in Southern Brazil: pileate species
}

\author{
Rosa Mara B. da Silveira ${ }^{1,3}$, Mateus A. Reck ${ }^{1}$, Letícia V. Graf ${ }^{2}$ and Flávia Nogueira de Sá ${ }^{2}$
}

Received: 14.08.2008; accepted: 12.11.2008

ABSTRACT - (Polypores from a Brazilian pine forest in Southern Brazil: pileate species). A fungal survey in the National Forest of São Francisco de Paula, in southern Brazil, displayed 38 pileate polypores species (eight Hymenochaetales and 30 Polyporales). Amauroderma coltricioides T.W. Henkel, Aime \& Ryvarden and Inonotus fulvomelleus Murrill are recorded for the fist time from Brazil, whereas Antrodiella multipileata Log.-Leite \& J.E. Wright and Junghuhnia minuta I. Lindblad \& Ryvarden are new records to Rio Grande do Sul State. Keys to species and remarks on the taxa are presented.

Key words: Basidiomycota, Hymenochaetales, Neotropical mycobiota, Polyporales

RESUMO - (Políporos de uma floresta de pinheiros no Sul do Brasil: espécies pileadas). Num estudo de fungos na Floresta Nacional de São Francisco de Paula, no sul do Brasil, 38 espécies de políporos pileados foram identificadas (oito Hymenochaetales e 30 Polyporales). Amauroderma coltricioides T.W. Henkel, Aime \& Ryvarden e Inonotus fulvomelleus Murrill são citadas pela primeira vez para o Brasil, enquanto Antrodiella multipileata Log.-Leite \& J.E. Wright e Junghuhnia minuta I. Lindblad \& Ryvarden são citações novas para o Rio Grande do Sul. Chaves para identificação e comentários sobre as espécies são apresentados.

Palavras-chave: Basidiomycota, Hymenochaetales, micobiota Neotropical, Polyporales

\section{Introduction}

The polypore mycobiota of southern Brazil is poorly known, with only a few papers published recently (Góes Neto et al. 2000, Ryvarden \& Meijer 2002, Groposo \& Loguercio-Leite 2005, Meijer 2006, Dreschler-Santos et al 2008, Loguercio-Leite et al 2008). In the case of Rio Grande do Sul State, Rick (1960) published a preliminary checklist for Polyporaceae and Meruliaceae. More recently, Silveira \& Guerrero (1991) provided an inventory of the polypores in Araucaria forests at Aparados da Serra National Park and Groposo \& LoguercioLeite (2002) provided a similar inventory in gallery forests at Cachoeirinha city. Rio Grande do Sul is the southernmost State of Brazil, and presents distinct types of vegetation which comprises forests and grasslands. The northeast of the State, included in the Atlantic rain forest domain (Brasil 2007), presents the Mixed Ombrophilous Forests, which present as canopy dominant species the conifer Araucaria angustifolia (Bertol.) Kuntze (Brazilian pine).
In order to provide new knowledge on the polypore fungi from Brazil and Rio Grande do Sul, 38 pileate species collected in São Francisco de Paula National Forest are discussed in the present work.

\section{Material and methods}

Study area - São Francisco de Paula National Forest (FLONA/SFP), is located in an Araucaria forest region, at the Rolante river basin, in a plateau in the northeast of Rio Grande do Sul State (29 $23^{\circ}$ - $29^{\circ} 27^{\prime}$ 'S and $50^{\circ} 23^{\prime}-50^{\circ} 25^{\prime} \mathrm{W}$ ), southern Brazil (Dobrovolski et al. 2006). FLONA/SFP has a total area of 1.606 ha, characterized by a mosaic of native forest (40\%) and Araucaria angustifolia, Pinus spp. and Eucalyptus spp. plantations. According to Köppen system, the climate type is $\mathrm{Cfb}$, with a fresh summer and a cold winter (Bitencourt et al. 2004).

Methods - The specimens were collected from August 2006 to March 2007. Basidiomata were macro and micromorphologically analyzed following usual methods for the study of polypores (Núñez \&

1. Universidade Federal do Rio Grande do Sul, Departamento de Botânica, Av. Bento Gonçalves, 9500, 91501-970 Porto Alegre, RS, Brazil

2. Universidade Federal do Rio Grande do Sul, Departamento de Ecologia, Av. Bento Gonçalves, 9500, 91501-970 Porto Alegre, RS, Brazil

3. Corresponding author: rosa.silveira@ufrgs.br 
Ryvarden 2001). Microscopic examination was made from freehand sections mounted in a drop of 5\% $\mathrm{KOH}$ solution and $1 \%$ phloxine solution; amyloid or dextrinoid reactions were observed in Melzer's reagent. Selected voucher specimens were deposited at ICN herbarium (Universidade Federal do Rio Grande do Sul, Brazil). Authors of fungal names are according to Kirk \& Ansell (1992) (www.indexfungorum. org/Names/AuthorsOfFungalNames.asp). World databases of fungal names were accessed at http:// www.indexfungorum.org.

\section{Results and Discussion}

In the present work 38 species pertaining to the orders Hymenochaetales and Polyporales are identified. In the order Hymenochaetales were found eight species, all includes in the family Hymenochaetaceae. The 30 species founded in Polyporales are includes in five families, named Ganodermataceae (two species), Grammotheleaceae (one species), Meripilaceae (three species), Polyporaceae (18 species) and Steccherinaceae (six species).

Key to species of Hymenochaetales

1. Basidiomata laterally or centrally stipitate, usually on the ground Phylloporia spathulata

1. Basidiomata pileate, sessile or sometimes with a lateral, tapering base, on dead wood

2. Hyphal system monomitic

3. Hymenial setae hooked Inonotus fulvomelleus

3. Hymenial setae straight Cyclomyces tabacinus

2. Hyphal system dimitic with skeletal hyphae

4. Hymenial setae present

5. Basidiomata perennial, hymenial setae hooked and straight in the same pileus

Phellinus wahlbergii

5. Basidiomata annual, rarely perennial, hymenial setae always straight

Phellinus gilvus

4. Hymenial setae absent

6. Basidiospores hyaline, dextrinoid in Melzer's reagent

Phellinus apiahynus

6. Basidiospores golden yellow to rusty brown, not dextrinoid

7. Basidiospores ellipsoid, 3-4 $\mu \mathrm{m}$ wide

Phellinus grenadensis

7. Basidiospores subglobose, $4-5.5 \mu \mathrm{m}$ wide Phellinus fastuosus

Key to species of Polyporales

1. Basidiomata laterally or centrally stipitate

2. Basidiomata on the ground, basidiospores globose, thick-walled Amauroderma coltricioides

2. Basidiomata on dead wood, basidiospores cylindric to ellipsoid, thin-walled

3. Stipe central, light brown, concolorous with pileus surface Polyporus ciliatus

3. Stipe eccentric to lateral, dark brown to black, sometimes only at the base

4. Pores large, 2-4 per mm, pileus flabelliform to petaloid Polyporus virgatus

4. Pores small, 6-9 per mm, pileus circular to spathulate

5. Pileus surface cream to light brown, smooth to radially, finely striated

5. Pileus surface brown to vinaceous brown, smooth Polyporus varius

ata pileate, sessile or sometimes with a lateral, tapering base Polyporus dictyopus

1. Basidiomata pileate, sessile or sometimes
6. Hymenophore lamellate to daedaleoid Lenzites betulina

6. Hymenophore poroid

7. Basidiospores truncate, golden-brown, wall double, echinulate Ganoderma australe

7. Basidiospores globose to cylindric, hyaline, wall simple, smooth

8. Generative hyphae with simple septa 
9. Hyphal system dimitic with binding hyphae, basidiospores ellipsoid

9. Hyphal system monomitic, basidiospores globose to subglobose

Laetiporus sulphureus

10. Basidiomata laterally attached by a distinct umbo or by a tapering base

10. Basidiomata effused-reflexed to dimidiate

11. Basidiomata large up to $6 \mathrm{~cm}$ thick, basidiospores 5-10 $\mu \mathrm{m}$ wide

Rigidoporus concrescens

11. Basidiomata smaller up to $1 \mathrm{~cm}$ thick, basidiospores 3.5-4 $\mu \mathrm{m}$ wide

Rigidoporus ulmarius

Rigidoporus microporus

8. Generative hyphae with clamps

12. Cystidia present in the hymenium or trama

13. Basidiomata perennial, skeletal hyphae dextrinoid, basidiospores thick-walled

Perenniporia martii

13. Basidiomata annual, skeletal hyphae not dextrinoid, basidiospores thin-walled

14. Hyphal system monomitic, gloeocystidia present Tyromyces hypocitrinus

14. Hyphal system di-trimitic, thick-walled cystidia present

15. Pore surface grayish to vinaceous, basidiospores cylindric to ellipsoid Trichaptum sector

15. Pore surface sulphur yellow or cream, basidiospores broadly ellipsoid to subglobose

16. Pore surface sulphur yellow Flaviporus brownei

16. Pore surface cream

17. Pores small, 7-9 per mm, basidiospores $2.5-3 \times 2-2.5 \mu \mathrm{m}$

Junghuhnia minuta

17. Pores medium-sized, 5-7 per mm, basidiospores 4-5 × 3.5-4 $\mu \mathrm{m}$ Junghuhnia undigera

12. Cystidia absent

18. Hyphal system trimitic, basidiospores cylindric

19. Pores large, 1-4 per mm, basidiomata coriaceous

20. Pileus surface dark brown to black, pore surface buff to umber brown, basidiomata easily separable from the substrate Datronia mollis

20. Pileus surface ochraceus, cinnamon-brown to grey dirty brown, firmly attached to the substrate

21. Pore surface white to cream, basidiospores 5.5-8.5 × 2.5-3.5 $\mu \mathrm{m}$ Trametes villosa

21. Pore surface cinnamon-brown, basidiospores 8-11(-14) $\times 2.5$ $4(-5) \mu \mathrm{m}$ Coriolopsis rigida

19. Pores medium sized to small, $4-8$ per $\mathrm{mm}$, basidiomata coriaceous to woody

22. Pore and pileus surfaces orange red Pycnoporus sanguineus

22. Basidiomata differently coloured

23. Pore surface dark, brown grey to vinaceous

24. Pore surface brown grey to dark grey, basidiospores cylindric, 6-9 $\times 2.5-3.5 \mu \mathrm{m}$ Fomitella supina

24. Pore surface vinaceous to vinaceous brown, basidiospores ellipsoid, 4-5 × 2.5-3 $\mu \mathrm{m}$ Abundisporus subflexibilis

23. Pore surface light-coloured, cream to ochraceous

25. Basidiomata large, up to $8 \mathrm{~cm}$ wide, basidiospores cylindric, 7-9.5 × 3-3.5 $\mu \mathrm{m}$ Trametes cubensis

25. Basidiomata smaller, 2-6 cm, basidiospores cylindric to oblong, 4-6 × 1.5-3 $\mu \mathrm{m}$ Trametes membranacea 
18. Hyphal system mono-dimitic, basidiospores broadly ellipsoid to subglobose

26. Pore surface grey to black Bjerkandera adusta

26. Pore surface white

27. Hyphal system monomitic, basidiospores allantoid Tyromyces leucomallus

27. Hyphal system dimitic, basidiospores ellipsoid

28. Pileus surface orange to light brown, concentrically zoned ..... Flaviporus subhydrophilus

28. Pileus surface white azoned, fleshy and brittle when fresh, becomes hard as bones and zoned when dried

29. Basidiospores $4-5 \times 3 \mu \mathrm{m}$ Antrodiella multipileata

29. Basidiospores $2.5-3.5 \times 1.5-2.5 \mu \mathrm{m}$ Antrodiella liebmannii

Hymenochaetales

\section{HYMENOCHAETACEAE}

Cyclomyces tabacinus (Mont.) Pat., Essai taxonomique sur les familles et les genres des Hyménomycètes: 98. 1900.

Description: Ryvarden (2004).

This species is characterized by its thin, flexible, dark brown colored basidiomata with tiny pores (7-9 per $\mathrm{mm}$ ), duplex context and monomitic hyphal system. This species was record by Silveira \& Guerrero (1991).

Specimens examined: BRAZIL. Rio GRANDE do SUL: São Francisco de Paula, FLONA, 19-VIII-2006, L.V. Graf 15 (ICN); idem, 2-IX-2006, L.V. Graf 56 (ICN); idem, 26-II-2007, L.V. Graf 289 (ICN).

Inonotus fulvomelleus Murrill, North American Flora 9(2): 87. 1908.

Figures 1-2

Description: Ryvarden (2004).

The hispid and villose pileus and the small pores (4-5 per $\mathrm{mm}$ ) characterize macroscopically this species. Microscopically, the monomitic hyphal system, the ellipsoid to short cylindric basidiospores (6-7.5 $\times 4-5 \mu \mathrm{m})$ and mainly the large hooked setae are the diagnostic characters. First record for Brazil.

Specimen examined: BRAZIL. Rio GRANDE do Sul: São Francisco de Paula, FLONA, 2-XI-2006, L.V. Graf 156 (ICN).

Phellinus apiahynus (Speg.) Rajchenb. \& J.E.Wright, Mycologia 79(2): 251. 1987.

Description: Ryvarden (2004).

This species has perennial, ungulate to applanate basidioma, and small, dextrinoid, subglobose basidiospores $(5-6 \times 4.5-5 \mu \mathrm{m})$. Phellinus robustus (P. Karst.) Bourdot \& Galzin, a related species that is only found in the temperate Northern Hemisphere, has larger basidiospores.

Specimen examined: BRAZIL. Rio GRANDE do Sul: São Francisco de Paula, FLONA, 6-X-2006, L.V. Graf 138 (ICN).

Phellinus fastuosus (Lév.) S. Ahmad, Basidiomycetes of West Pakistan: 56. 1972.

Description: Ryvarden (2004).

It is recognized by the perennial, often large and applanated basidiomata [up to $60 \mathrm{~cm}, 30 \mathrm{~cm}$ wide and $7 \mathrm{~cm}$ thick, according to Ryvarden (2004)] and, microscopically, by the lack of setae.

Specimen examined: BRAZIL. Rio GRANDE do Sul: São Francisco de Paula, FLONA, 24-III-2007, L.V. Graf 351 (ICN).

Phellinus gilvus (Schwein) Pat., Essai taxonomique sur les familles et les genres des Hyménomycètes: 97. 1900.

Description: Ryvarden (2004).

Its pileus shows many shapes and sizes. However, it can be recognized by thin and usually dimidiate basidiomata, that presents a rugose, upper surface of brown-rusty color. Its diagnostic characters are the ellipsoid to ovoid basidiospores $(3-5 \times 2-3 \mu \mathrm{m})$ and the usually abundant setae, which are ventricose to subulate. This species was record by Silveira \& Guerrero (1991).

Specimens examined: BRAZIL. Rio GRANDE do Sul: São Francisco de Paula, FLONA, 4-XII-2006, L.V. Graf 215 (ICN); idem, 26-II-2007, L.V. Graf 299 (ICN). 


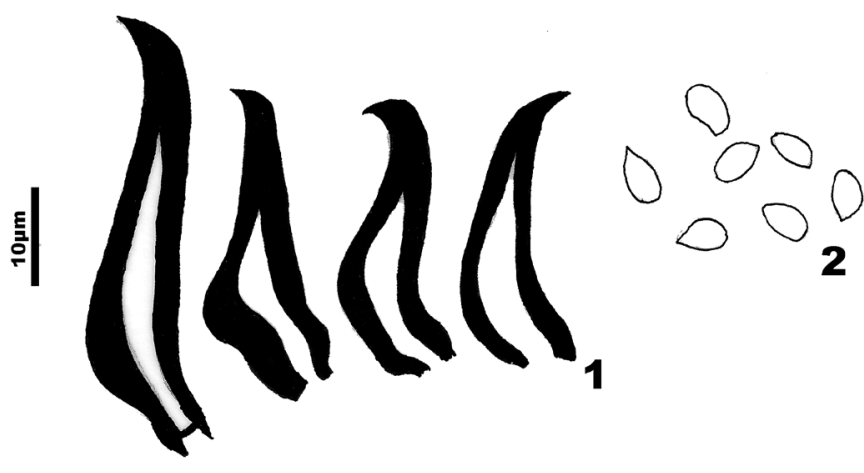

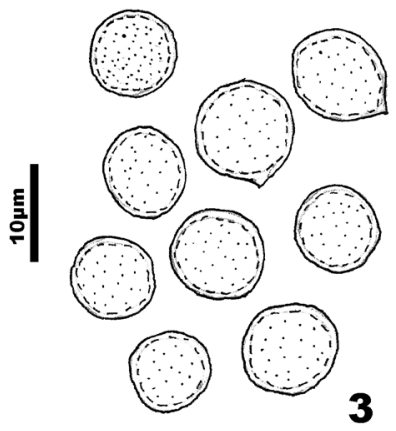
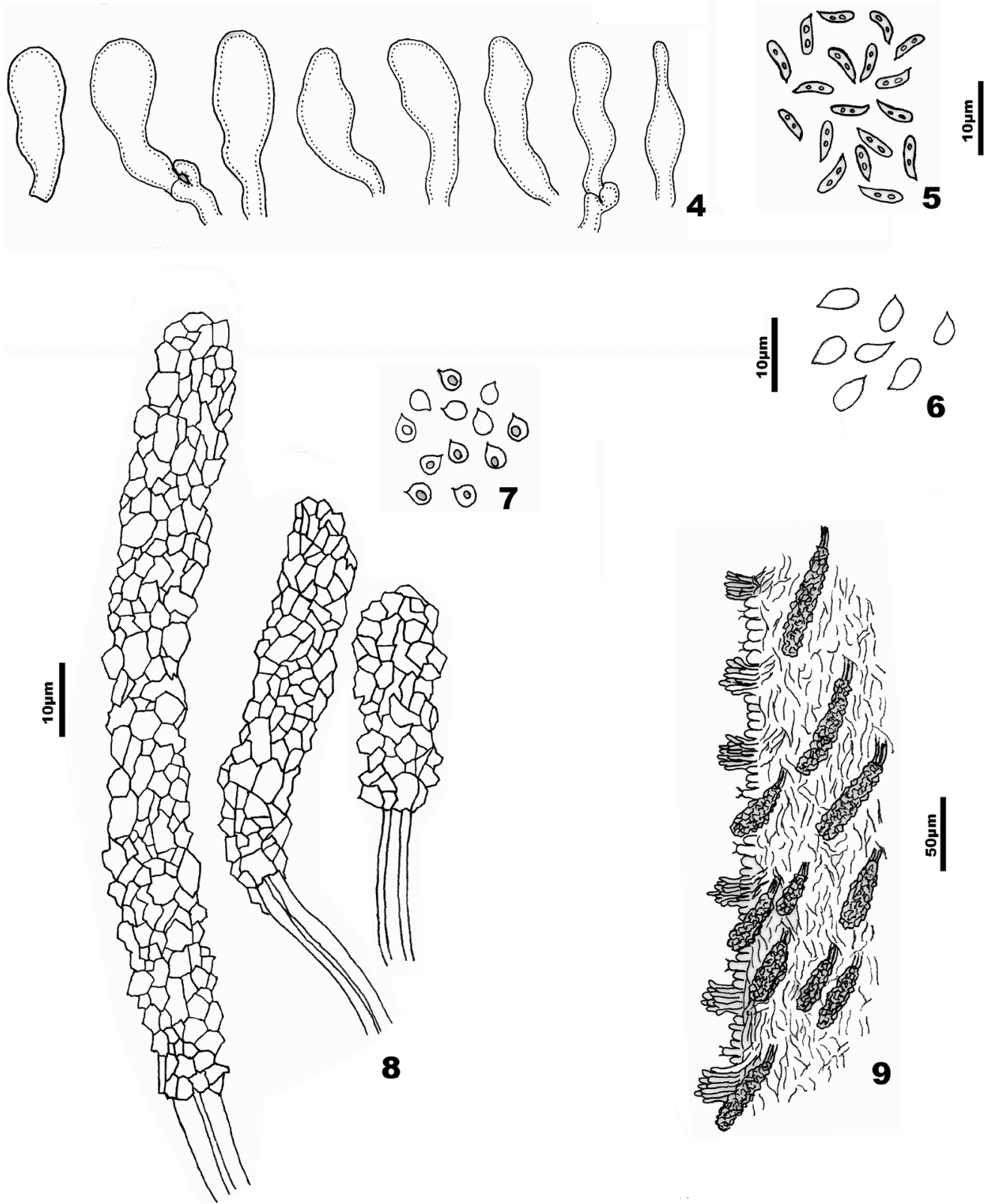

Figures 1-9. Microscopic characters of some polypores. 1-2. Inonotus fulvomelleus. 1. Hymenial setae. 2. Basidiospores. 3. Basidiospores of Amauroderma coltricioides. 4-5. Tyromyces hypocitrinus. 4. Gloeocystidia. 5. Basidiospores. 6. Basidiospores of Antrodiella multipileata. 7-9. Junghuhnia minuta. 7. Basidiospores. 8. Encrusted cystidia. 9. Section of trama showing cystidia and hyphal pegs. 
Phellinus grenadensis (Murrill) Ryvarden, Norwegian Journal of Botany 19: 234. 1972.

Description: Ryvarden (2004).

This species is characterized by a dimidiate to ungulate pileus with a distinct crust, stratified tubes separated by context-layers and the lack of setae. The ellipsoid basidiospores (3-4 $\mu \mathrm{m}$ wide) distinguish this species from Phellinus fastuosus, which has subglobose basidiospores (4-5.5 $\mu \mathrm{m}$ wide).

Specimens examined: BRAZIL. Rio GRANDE do SuL: São Francisco de Paula, FLONA, 30-I-2007, L.V. Graf 231 (ICN); idem, 26-II-2007, L.V. Graf 335 (ICN).

Phellinus wahlbergii (Fr.) D.A. Reid, Contributions from the Bolus Herbarium 7: 97. 1975.

Description: Ryvarden (2004).

This species is recognized by the perennial, woody basidiome and, principally, by the presence of setae that can be straight or hooked, both found in the same pileus. This species was record by Silveira \& Guerrero (1991).

Specimens examined: BRAZIL. Rio Grande do Sul: São Francisco de Paula, FLONA, 19-VIII-2006, L.V. Graf 43 (ICN); idem, 2-IX-2006, L.V. Graf 93 (ICN).

Phylloporia spathulata (Hook.) Ryvarden, Synopsis Fungorum 5: 196. 1991.

Description: Ryvarden (2004).

The stipitated basidiomata, with a thin dark zone below the adpressed tomentum, both in the pileus and in the stipe, together with the minute pores (7-9 per $\mathrm{mm})$, the small basidiospores $(3-4 \times 2-3 \mu \mathrm{m})$ and the hard consistency characterize the species. According to Ryvarden (2004) this is a variable species considering the shape and size of the basidiome.

Specimens examined: BRAZIL. Rio Grande do Sul: São Francisco de Paula, FLONA, 30-I-2007, L.V. Graf 242 (ICN); 26-II-2007, L.V. Graf 290 (ICN); 26-II2007, L.V. Graf 302 (ICN).

Polyporales

\section{GANODERMATACEAE}

Amauroderma coltricioides T.W. Henkel, Aime \& Ryvarden, Mycologia 95(4): 615. 2003.

Figure 3
Description: Ryvarden (2004).

The species is recognized in the field by its stipitated and brown colored basidiomata, which grows on the ground. Macroscopically it looks exactly like a Coltricia species, but is easily distinguished by its clamped generative hyphae and arboriform skeletal hyphae (Ryvarden 2004). The globose, thick-walled and smooth basidiospores $(6.5-7 \mu \mathrm{m})$, an exception in Ganodermataceae, characterize the species. First record for Brazil.

Specimens examined: BRAZIL. Rio GRANDE Do SUL: São Francisco de Paula, FLONA, 26-II-2007, L.V. Graf 291 (ICN); idem, L.V. Graf 323 (ICN); idem, 24-III-2007, L.V. Graf 363 (ICN).

Ganoderma australe (Fr.) Pat., Bulletin de la Société Mycologique de France 5: 71. 1889.

Description: Ryvarden (2004).

This is one of the most abundant species in the studied area and also in Rio Grande do Sul State. Its perennial basidiomata, with brown-chocolate upper surface and beige hymenial surface, are found all the year round. It can grow up to $50 \mathrm{~cm}$ in length. It is microscopically characterized by truncated, ornamented basidiospores with double walls (7.5-11.5 $\times 5.5-8 \mu \mathrm{m})$. In previous works, such as Silveira \& Guerrero (1991), it has been determined as Ganoderma applanatum (Pers.) Pat.

Specimen examined: BRAZIL. Rio GRANDE do Sul: São Francisco de Paula, FLONA, 6-X-2006, L.V. Graf 131 (ICN).

\section{GRAMMOTHELEACEAE}

Bjerkandera adusta (Willd.) P. Karst., Meddelanden af Societas pro Fauna et Flora Fennica 5: 38. 1879.

Description: Gilbertson \& Ryvarden (1986).

This species is characterized by the effusedreflexed and thin basidiomata, with light yellow pilear surface and grey hymenial surface, which becomes very dark when it gets old. Its diagnostic characters are the ellipsoid basidiospores $(4-5.5 \times 2.5-3.5 \mu \mathrm{m})$ and the monomitic hyphal system with thick-walled, wide hyphae with large clamps in the context.

Specimen examined: BRAZIL. Rio GRANDE do Sul: São Francisco de Paula, FLONA, 4-XII-2006, L.V. Graf 224 (ICN). 


\section{MERIPILACEAE}

Rigidoporus concrescens (Mont.) Rajchenb., Boletín de la Sociedad Argentina de Botánica 28(1-4): 165. 1992.

Description: Rajchenberg (1987, as Rigidoporus umbonatipes Rajchenb.).

This species is very abundant in the study area. The presence of an umbo that attaches the basidiome to the substrate, identify macroscopically this species. Its basidiomata vary in shape, with pilei that can grow together and that may cover the entire trunk. This species was record by Silveira \& Guerrero (1991) as Rigidoporus umbonatipes.

Specimen examined: BRAZIL. Rio GRANDE Do SuL: São Francisco de Paula, FLONA, 4-XII-2006, L.V. Graf 203 (ICN).

Rigidoporus microporus (Sw.) Overeem, Icon. fung. malay. 5:1. 1924.

Description: Gilbertson \& Ryvarden (1987).

The species shows effused-reflexed to dimidiate basidiomata. It has an orange-red-brownish color and a slightly velutinate upper surface when young, and a glabrous and fading to wood color when it gets old. It shows a concentrically sulcated zonation and light color of hymenial surface with small pores (6-10 per $\mathrm{mm}$ ). Microscopically, the hyphal system is monomitic with simple septate generative hyphae and the globose basidiospores (4-5.5 $\mu \mathrm{m})$. R. microporus is distinguished from $R$. lineatus (Pers.) Ryvarden by the absence of cystidia.

Specimens examined: BRAZIL. Rio GRANDE do SUL: São Francisco de Paula, FLONA, 26-II-2007, L.V. Graf 287 (ICN); idem, 26-II-2007, L.V. Graf 304 (ICN).

Rigidoporus ulmarius (Sowerby) Imazeki, Bulletin of the Government Forest Experimental Station Meguro 57: 97. 1952.

Description: Gilbertson \& Ryvarden (1987).

The perennial (up to $70 \times 30 \times 10 \mathrm{~cm}$ ) and light yellow colored basidiomata, which are corky when fresh and very hard upon drying characterize macroscopically this species, that is sometimes found on living trees. Microscopically it shows globose basidiospores $(6-8 \mu \mathrm{m})$ and ventricose to fusoid cystidioles. This species was record by Silveira \& Guerrero (1991).
Specimen examined: BRAZIL. Rio GRANDE do Sul: São Francisco de Paula, FLONA, 30-I-2007, L.V. Graf 259 (ICN).

\section{POLYPORACEAE}

Abundisporus subflexibilis (Berk. \& M.A. Curtis) Parmasto, Karstenia 40: 134. 2000.

Description: Parmasto \& Hallenberg (2000).

This species shows a pileate, imbricate basidiome. Its pilear surface has concentric zones of brownish to dark-brown colors. The vinaceous brown hymenophore and the dimitic hyphal system are characteristics of the genus. The ellipsoid basidiospores $(4-5 \times 2.5-3 \mu \mathrm{m})$ with slightly thick walls separates this species from Nigroporus vinosus (Berk.) Murrill, which is another species of Southern Brazil. This taxon was recorded for Rio Grande do Sul by Rick (1960) as Polyporus vibratilis Berk. \& M.A. Curtis.

Specimens examined: BRAZIL. Rio Grande do Sul: São Francisco de Paula, FLONA, 2-IX-2006, L.V. Graf 91 (ICN); idem, 24-III-2007, L.V. Graf 368 (ICN).

Coriolopsis rigida (Berk. \& Mont.) Murrill, North American Flora 9(2): 75. 1908.

Description: Gilbertson \& Ryvarden (1986).

A species with variable basidiomata in both form and size. However, it can be easily identified by its typical shape, with effused-reflexed basidiomes, firmly attached to the substrate, and by its ochraceous to cinnamon-brown color. A trimitic hyphal system and cylindrical basidiospores can also be found in Trametes Fr. species and in Pycnoporus sanguineus (L.) Murrill, but it differentiates from them by the ochraceous color of the basidioma and context hyphae. This species was record by Silveira \& Guerrero (1991).

Specimen examined: BRAZIL. Rio Grande do Sul: São Francisco de Paula, FLONA, 4-XII-2006, L.V. Graf 213 (ICN).

Datronia mollis (Sommerf.) Donk, Persoonia 4(3): 338. 1966.

Description: Gilbertson \& Ryvarden (1986).

The pileus has dark-brown to black color and detaches easily from the substrate. It has a beige color hymenial surface with big irregular pores (1-2 per $\mathrm{mm})$. All these features allow its field recognition. It is microscopically characterized by a trimitic hyphal 
system and cylindric basidiospores $(7.5-11 \times 3-4.5$ $\mu \mathrm{m})$. This species was record by Silveira \& Guerrero (1991).

Specimens examined: BRAZIL. RIo GRANDE DO SUL: São Francisco de Paula, FLONA, 2-IX-2006, L.V. Graf 55 (ICN); idem, 6-X-2006, L.V. Graf 107 (ICN).

Fomitella supina (Sw.) Murrill, Bulletin of the Torrey Botanical Club 32(7): 365. 1905.

Description: Gilbertson \& Ryvarden (1986).

The basidiomata are effused-reflexed to dimidiate, sometimes imbricate. Its pilear surface is pale ochraceous in color, but it usually presents/develops a dark crust on the base or all over its surface. The hymenophore has small pores (6-7 per $\mathrm{mm}$ ) and darkgrey pore surface. It is microscopically characterized by a trimitic hyphal system and cylindrical basidiospores $(6-7 \times 2-3 \mu \mathrm{m})$.

Specimens examined: BRAZIL. Rio GRANDE Do SUL: São Francisco de Paula, FLONA, 6-X-2006, L.V. Graf 129 (ICN); idem, 26-II-2007, L.V. Graf 326 (ICN).

Laetiporus sulphureus (Bull.) Murrill, Mycologia 12(1): 11. 1920.

Description: Gilbertson \& Ryvarden (1986).

It is easily identified in the field by the yelloworange pileus with fleshy consistency, and the sulphureous to citric yellow pore surface. The basidiospores are subglobose $(5.5-7 \times 4.5-5 \mu \mathrm{m})$ and the hyphal system is dimitic, with simple septate generative hyphae.

Specimen examined: BRAZIL. Rio GRANDE do SUL: São Francisco de Paula, FLONA, 4-XII-2006, L.V. Graf 193 (ICN).

Lenzites betulina (L.) Fr., Epicrisis Systematis Mycologici: 405. 1838.

Description: Gilbertson \& Ryvarden (1986).

This species is easily recognized in the field by the lamellate and daedaleoid hymenophore. It is microscopically identified by a trimitic hyphal system, cylindric basidiospores $(5-6 \times 2-2.5 \mu \mathrm{m})$ and binding hyphae with sword-like branches - a pattern that can be confused with the cystidia. The pilear surface is tomentose in concentric zones, very similar to Trametes versicolor (L.) Lloyd which, however, has a tubular hymenophore. Our specimens showed 26 lamellae per $\mathrm{cm}$, which is the double of the number of lamellae in the specimens found by Ryvarden (1978) and Gilbertson \& Ryvarden (1986). It is possible that the studied specimen is a new variety. This species was record by Silveira \& Guerrero (1991).

Specimen examined: BRAZIL. Rio GRANDE do Sul: São Francisco de Paula, FLONA, 19-VIII-2006, L.V. Graf 026 (ICN).

Perenniporia martii (Berk.) Ryvarden, Norwegian Journal of Botany 19: 143. 1972.

Description: Ryvarden \& Johansen (1980).

The perennial ungulated basidiomata, with a dark brown pilear surface and cream white pore surface characterize macroscopically this species. It is identified microscopically by the basidiospores with thick-walls, pipshaped to weakly truncate (8-10 $\times 4.5-5.5 \mu \mathrm{m})$ and by the trimitic hyphal system with dextrinoid skeletal hyphae. According to Ryvarden \& Johansen (1980), the cystidia seem to be more common in the African and Asian specimens than in the American ones. We have not observed cystidia in our specimen.

Specimen examined: BRAZIL. Rio GRANDE do Sul: São Francisco de Paula, FLONA, 4-XII-2006, L.V. Graf 225 (ICN).

Polyporus ciliatus Fr., Observationes mycologicae 1: 123.1815.

Description: Silveira \& Wright (2005)

This species is characterized by its centrally stipitate, brown basidiomata with very light colored pore surface and small pores (5-7 per $\mathrm{mm}$ ). The pileus margin may be ciliated or not. It is one of the most common species of the genus in the study area. This species was record by Silveira \& Guerrero (1991).

Specimens examined: BRAZIL. Rio Grande do Sul: São Francisco de Paula, FLONA, 6-X-2006, L.V. Graf 212 (ICN); idem, 4-XII-2006, L.V. Graf 107 (ICN).

Polyporus dictyopus Mont., Annales Sci. nat., Bot. 3: 345.1835.

Description: Silveira \& Wright (2005).

The basidiomata has a brown to vinaceous-brown pilear surface, a dark stipe and a grayish pore surface with small pores (6-9 per $\mathrm{mm}$ ). This species was record by Silveira \& Guerrero (1991) as Polyporus blanchettianus. 
Specimens examined: BRAZIL. Rio GRANDE do Sul: São Francisco de Paula, FLONA, 2-IX-2006, L.V. Graf 80 (ICN); idem, 2-XI-2006, L.V. Graf 150 (ICN).

Polyporus varius (Pers.) Fr., Systema Mycologicum 1: 352. 1821.

Description: Silveira \& Wright (2005).

This species is easy to identify by its laterally stipitated basidiomata, light yellow to light brown colored, smooth to fine radially striated pileus and black stipe.

Specimen examined: BRAZIL. Rio GRANDE do Sul: São Francisco de Paula, FLONA, 19-VIII-2006, L.V. Graf 25 (ICN).

Polyporus virgatus Berk. \& M.A. Curtis, Journal of the Linnean Society, Botany 10: 304. 1868.

Description: Silveira \& Wright (2005).

This species has laterally stipitate basidiomata, flabelliform to petaloid, yellowish brown pileus with a dark lineal mark on the edge, and a black stipe.

Specimen examined: BRAZIL. Rio GRANDE do Sul: São Francisco de Paula, FLONA, X-2005, R.M. Silveira s.n. (ICN139436).

Pycnoporus sanguineus (L.) Murrill, Bulletin of the Torrey Botanical Club 31(8): 421. 1904.

Description: Gilbertson \& Ryvarden (1987).

This species shows a coriaceous basidioma of orange-reddish color, trimitic hyphal system and cylindric basidiospores $(4-5 \times 1.5-2.5 \mu \mathrm{m})$. It is very common in Rio Grande do Sul, especially in areas modified by man. This species was record by Silveira \& Guerrero (1991).

Specimen examined: BRAZIL. Rio GRANDE do Sul: São Francisco de Paula, FLONA, 30-I-2007, L.V. Graf 246 (ICN).

Trametes cubensis (Mont.) Sacc., Sylloge Fungorum 9: 198. 1891.

Description: Gilbertson \& Ryvarden (1987).

This species can be recognized in the field by the dimidiated basidioma, up to $20 \mathrm{~cm}$ in width, lightcolored (cream to ochraceous) and a hymenophore that has medium-sized to small pores [4-5(-6) per mm]. It is flexible when fresh and hard after drying. The pilear surface may show a brown-reddish stain close to the substrate attachment. A trimitic hyphal system and cylindric basidiospores characterize this species microscopically.

Specimen examined: BRAZIL. Rio Grande do Sul: São Francisco de Paula, FLONA, 2-XI-2006, L.V. Graf 190 (ICN).

Trametes membranacea (Sw.) Kreisel, Monografias, Ciencias, Universidad de Habana 16: 83. 1971.

Description: Gilbertson \& Ryvarden (1987).

It shows dimidiate to flabelliform basidiomata, with a fine velutinous surface that is sometimes glabrous. Its pileus is light yellow to light-grey and its hymenophore is also light colored, with small pores. This species can be separated from Trametes versicolor, which shows the same trimitic hyphal system and cylindric basidiospores, especially for presenting a tomentose pileus in bright colors (brown and grey). This species was record by Silveira \& Guerrero (1991).

Specimens examined: BRAZIL. Rio Grande do SuL: São Francisco de Paula, FLONA, 19-VIII-2006, L.V. Graf 27 (ICN); idem, L.V. Graf 39 (ICN); idem, 4-XII2006, L.V. Graf 210 (ICN).

Trametes villosa (Sw.) Kreisel, Monografias, Ciencias, Universidad de Habana 16: 83. 1971.

Description: Gilbertson \& Ryvarden (1987).

This species is easily identified by its effusedreflexed basidiomata, with concentric zonated upper surface of grey color and light colored hymenophore with big and shallow pores (2-4 per $\mathrm{mm}$ ). The hyphal system is trimitic and the basidiospores are cylindric. Trametes membranacea and T. versicolor (L.) Lloyd are similar but present small pores. This species was record by Silveira \& Guerrero (1991).

Specimen examined: BRAZIL. Rio GRANDE do Sul: São Francisco de Paula, FLONA, 2-IX-2006, L.V. Graf 83 (ICN).

Trichaptum sector (Ehrenb.) Kreisel, Monografias, Ciencias, Universidad de Habana 16: 84. 1971.

Description: Gilbertson \& Ryvarden (1987).

It is recognized in the field by its thin and flexible, beige to vinaceous basidiomata. It has a brown, zonated upper surface and a dark hymenophore with small pores (6-10 per mm). Microscopically, the apically incrusted cystidia and the cylindric and 
ellipsoid basidiospores $(5-7 \times 1.5-2.5 \mu \mathrm{m})$ are typical. This species was record by Silveira \& Guerrero (1991).

Specimen examined: BRAZIL. Rio GRANDE do Sul: São Francisco de Paula, FLONA, 2-IX-2006, L.V. Graf 60 (ICN).

Tyromyces hypocitrinus (Berk.) Ryvarden, Mycotaxon 20(2): 344. 1984.

Figures 4-5

Description: Ryvarden (1984).

The dimidiate, white to pale citric yellow basidiomata are similar to T. leucomallus (see below) but with larger pores (5-7 per $\mathrm{mm}$ ). The monomitic hyphal system, allantoid basidiospores (4-6 × 1-2 $\mu \mathrm{m})$ and gloeocystidia (absent in T. leucomallus) characterize the species microscopically. This species was record for fist time for Rio Grande do Sul by Rajchenberg (1987), in his study on Rick's polypore specimens.

Specimen examined: BRAZIL. Rio Grande Do Sul: São Francisco de Paula, FLONA, 10-IX-2005, M.A. Reck s.n. (ICN139446).

Tyromyces leucomallus (Berk. \& M.A. Curtis) Murrill, North American Flora 9(1): 36. 1907.

Description: Gilbertson \& Ryvarden (1987).

The species is recognized in the field by watery, dimidiate, white, white grayish to cream basidiomata and by a hymenophore with small pores (5-8 per $\mathrm{mm}$ ). The gloeoplerous hyphae together with the allantoid short basidiospores (3-4.5 × 0.8-1.5 um) are important diagnostic characters. This species was record for fist time for Rio Grande do Sul by Silveira \& Guerrero (1991).

Specimen examined: BRAZIL. Rio Grande do Sul: São Francisco de Paula, FLONA, 10-IX-2005, M.A. Reck s.n. (ICN139447).

\section{STECCHERINACEAE}

Antrodiella liebmannii (Fr.) Ryvarden, A preliminary polypore flora of East Africa: 257. 1980.

Description: Ryvarden \& Johansen (1980).

This species is characterized by white and cream colored basidiomata, with a fleshy and brittle consistency, that are easy to break when fresh but become hard as bones when dried. Some of the microscopic features are the subglobose spores (2.5-3 $\times 1.5-2 \mu \mathrm{m})$ and a dimitic hyphal system which has an agglutinant substance around its hyphae. In this species, however, the generative hyphae with clamps are difficult to observe in dried specimens. Cystidia are strongly colored by phloxine $1 \%$, but they are not easy to found. This species was previously recorded for Rio Grande do Sul as Polystictus stereinus (Berk. \& M.A. Curtis) Sacc. (Rick 1960) and Flaviporus sp. (Silveira \& Guerrero 1991).

Specimen examined: BRAZIL. Rio GRANDE do SUL: São Francisco de Paula, FLONA, 24-III-2007, L.V. Graf 356 (ICN).

Antrodiella multipileata Log.-Leite \& J.E. Wright, Mycotaxon 41(1): 167. 1991.

Figure 6

Description: Loguercio-Leite \& Wright (1991).

This species is characterized by having pileate to effused-reflexed basidiomata which are solitary or imbricate, white to cream, zonate, with a fleshy and brittle consistency that becomes hard as bones when dried. Microscopically the larger, ellipsoid basidiospores $(3.5-4.5 \times 2-2.5 \mu \mathrm{m})$ separates it from A. liebmannii. First record for Rio Grande do Sul.

Specimens examined: BRAZIL. Rio Grande do Sul: São Francisco de Paula, FLONA, 2-XI-2006, L.V. Graf 158 (ICN); idem, 24-III-2007, L.V. Graf 349 (ICN).

Flaviporus brownei (Humb.) Donk, Persoonia 1: 189. 1960.

Description: Ginns (1980).

The basidiomata of this species are easy to recognize due to a bright yellow-sulphur color. It presents a dimitic hyphal system with clamped generative hyphae and broadly ellipsoid basidiospores (2.6-2.8 $\times 1.8 \mu \mathrm{m})$, which are important diagnostic characters.

Specimen examined: BRAZIL. Rio Grande do Sul: São Francisco de Paula, FLONA, 24-III-2007, L.V. Graf 354 (ICN).

Flaviporus subhydrophilus (Speg.) Rajchenb. \& J.E. Wright, Mycologia 79(2): 259. 1987.

Description: Rajchenberg \& Wright (1987). 
The individuals of this species have oranged color basidiomata with a zonated pilear surface. It has a white to cream pore surface and very small pores. The hyphal system is dimitic and the basidiospores are ellipsoid $(2.7-3.6 \times 1.5-2.1 \mu \mathrm{m})$. This species was record by Silveira \& Guerrero (1991).

Specimen examined: BRAZIL. Rio Grande do Sul: São Francisco de Paula, FLONA, 30-I-2007, L.V. Graf 234 (ICN).

Junghuhnia minuta I. Lindblad \& Ryvarden, Mycotaxon 71: 346. 1999.

Figures 7-9

Description: Lindblad \& Ryvarden (1999).

The species is characterized by tiny, glabrous, pale brown and dense basidiomata, often with several small fan shaped basidiomata growing in clusters. Microscopically, the dimitic hyphal system and mainly the tiny basidiospores $(2.5-3.5 \times 2-2.5 \mu \mathrm{m})$ are diagnostic characters. First record for Rio Grande do Sul.

Specimen examined: BRAZIL. Rio GRANDE do SUL: São Francisco de Paula, FLONA, 24-III-2007, L.V. Graf 340 (ICN).

Junghuhnia undigera (Berk. \& M.A. Curtis) Ryvarden, Mycotaxon 20(2): 359. 1984.

Description: Ryvarden (1984).

This species is recognized by the small and thin basidiomata, which are usually imbricated and light colored (white to cream). It has large, thick-walled, encrusted cystidia, subglobose basidiospores (4-4.5 $\times$ 3-4 $\mu \mathrm{m})$ and dimitic hyphal system. This species was record by Silveira \& Guerrero (1991).

Specimens examined: BRAZIL. Rio GRANDE Do Sul: São Francisco de Paula, FLONA, 24-III-2007, L.V. Graf 342 (ICN); idem, 24-III-2007, L.V. Graf 369 (ICN).

\section{Acknowledgements}

The authors acknowledge Mr. José Arthur Soligo and Edenice Souza on behalf of Brazilian enviroment institute (IBAMA) for permit and fieldwork support. The authors are indebted to Edilena Sperb and Fabricia Barbieri for assistance during field work. CAPES and CNPq (Brazil) are acknowledged for financial support.

\section{Literature cited}

Bitencourt, A.L.V., Hasenack, H., Mauhs, J. 2004. Estudo do padrão atual da Floresta Ombrófila Mista e Campos em duas unidades de conservação e imediações: Floresta Nacional de São Francisco de Paula e Reserva Ecológica de Aracuri, RS. Anais da XI Reunião de Paleobotânicos e Palinólogos. Universidade Federal do Rio Grande do Sul, Porto Alegre.

BRASIL. 2007. Áreas Prioritárias para Conservação, Uso Sustentável e Repartição de Benefícios da Biodiversidade Brasileira: Atualização - Portaria MMA $\mathrm{n}^{\circ}$ 9, de 23 de janeiro de 2007. Série Biodiversidade, 31 Ministério do Meio Ambiente, Secretaria de Biodiversidade e Florestas, Brasília.

Dobrovolski, R., Both, R., Coelho, I.P., Stolz, J.F.B., Schüssler, G., Rodrigues, G.G., Geurra, T. \& Hartz, S.M. 2006. Levantamento de áreas prioritárias para a conservação da Floresta Nacional de São Francisco de Paula (RS, Brasil) e seu entorno. Revista Brasileira Biociências 4: 7-14.

Drechsler-Santos, E.R., Groposo, C., Loguercio-Leite, C. 2008. Additions to the knowledge of lignocellulolytic Basidiomycetes (Fungi) in forests from Santa Catarina State, Brazil. Mycotaxon 103: 197-200.

Gilbertson, R.L. \& Ryvarden, L. 1986. North American polypores. v.1 Abortiporus - Lindtneria. Fungiflora, Oslo.

Gilbertson, R.L. \& Ryvarden, L. 1987. North American polypores. v.2 Megasporoporia - Wrightoporia. Fungiflora, Oslo.

Ginns, J. 1980. The genus Flaviporus Murr. (Polyporaceae). Canadian Journal of Botany 58: 1578-1590.

Groposo, C., Loguercio-Leite, C. 2002. Fungos poliporóides xilófilos (Basidiomycetes) da Reserva Biológica Tancredo Neves, Cachoeirinha, Rio Grande do Sul, Brasil. Iheringia, série Botânica 57: 39-59.

Groposo, C., Loguercio-Leite, C. 2005. Contribution to the lignocellulolytic fungi (Basidiomycetes) of the Atlantic Rain Forest in Southern Brazil. Mycotaxon 92: 103-106.

Góes Neto, A., Loguercio-Leite, C. \& Guerrero, R.T. 2000. Poroid Hymenochaetales in a seasonal tropical forest fragment in the State of Bahia, Brazil: taxonomy and qualitative ecological aspects. Mycotaxon 76: 197-211.

Kirk, P.M. \& Ansell, A.E. 1992. Authors of fungal names. Index of Fungi supplement. CAB International, Wallingford.

Lindblad, I. \& Ryvarden, L. 1999. Studies in Neotropical polypores 3. New and interesting Basidiomycetes (Poriales) from Costa Rica. Mycotaxon 71: 335-359.

Loguercio-Leite, C. \& Wright, J.E. 1991. New South American pileate polypores (Polyporaceae) from Santa 
Catarina Island, SC, Brazil. Mycotaxon 41: 167-172.

Loguercio-Leite, C., Michels, J., Baltazar, J.M. 2008 . Austro-American lignolitic polypores (Agaricomycetes) new records for Southern Brazil. Mycotaxon 104: 205-213.

Meijer, A.A.R. 2006. Preliminary list of macromycetes from the Brazilian State of Paraná. Boletim do Museu Botânico Municipal 68: 1-55.

Núñez, M. \& Ryvarden, L. 2001. East Asian polypores. Synopsis Fungorum 13: 1-168.

Parmasto, E. \& Hallenberg, N. 2000. The genus Abundisporus (Hymenomycetes, Basidiomycotina). Karstenia 40: 129-138.

Rajchenberg, M. 1987. New South American polypores. Mycotaxon 28: 111-118.

Rajchenberg, M. \& Wright, J.E. 1987. Type studies of Corticiaceae and Polyporaceae (Aphyllophorales) described by C. Spegazzini. Mycologia 79: 246-264.

Rick, J. 1960. Basidiomycetes Eubasidii in Rio Grande do Sul - Brasilia 4. Meruliaceae, Polyporaceae e Boletaceae. Iheringia, série Botânica 7: 193-295.
Ryvarden, L. 1978. The Polyporaceae of North Europe. v.2 Inonotus - Tyromyces. Fungiflora, Oslo.

Ryvarden, L. 1984. Types studies in the Polyporaceae 16. Species described by J.M.Berkeley, either alone or with other mycologists from 1856 to 1886 . Mycotaxon 20: 329-363.

Ryvarden, L. 2004. Neotropical Polypores Part 1. Introduction, Ganodermataceae \& Hymenochaetaceae. Synopsis Fungorum 19: 1-229.

Ryvarden, L. \& Johansen, I. 1980. A preliminary polypore flora of East Africa. Fungiflora, Oslo.

Ryvarden, L. \& Meijer, A.A.R. 2002. Studies in neotropical polypores 14. New species from the state of Paraná, Brazil. Synopsis Fungorum 15: 34-69.

Silveira, R.M.B. \& Guerrero, R.T. 1991. Aphyllophorales poliporóides (Basidiomycetes) do Parque Nacional de Aparados da Serra, Rio Grande do Sul. Boletim do Instituto de Biociências 48: 1-127.

Silveira, R.M.B. \& Wright, J.E. 2005. The taxonomy of Echinochaete and Polyporus s. str. in southern South América. Mycotaxon 93: 1-59. 